\title{
Short Communication: The species and body size composition of pelagic fishes that caught by troll line in the fish landing of Sendang Biru, East Java, Indonesia
}

\author{
DEWI HIDAYATI", BUGGIE OCLANDHI, NOVA MAULIDINIA, NOOR NAILIS SA'ADAH, \\ AWIK PUJI DYAH NURHAYATI \\ Department of Biology, Faculty of Science, Institut TeknologiSepuluh Nopember. Jl. Arief Rahman Hakim, Keputih, Sukolilo, Surabaya 60111, East \\ Java, Indonesia. Tel./fax.+62-31-5963857, `email: dewi_hidayati@ymail.com
}

Manuscript received: 19 March 2019. Revision accepted: 30 May 2019.

\begin{abstract}
Hidayati D, Oclandhi B, Maulidinia N, Sa'adah NN, Nurhayati APD. 2019. Short Communication: The species and body size composition of pelagic fishes that caught by troll line in the fish landing of Sendang Biru, East Java, Indonesia. Biodiversitas 20: 17641769. Troll line is the most used pelagic fishing gear for fishermen in Sendang Biru, the part of Indian ocean at East Java, which have an impact on the catch composition. The study was aimed to obtain data on species composition and size of pelagic fish caught in troll line in Sendang Biru, East Java, Indonesia. Fish samples were collected from nine different vessels landed in Sendang Biru for three days in April 2018. The composition of fish species was measured based on relative abundance. The fish size composition was obtained by measuring fork length which is also used to determine the stage of development of juvenile (Jv) or adult (Ad) fish. The results of the research showed there were four pelagic fish species which dominated by Katsuwonus pelamis or skipjack tuna (50.05\%) and Thunnus albacares or yellowfin tuna (47.95\%) and a small amount of Coryphaena hippurus and Makaira mazara. According to the body size, the fish caught by troll line in Sendang Biru is dominated by adult skipjack tuna $(41-60 \mathrm{~cm})$ and juvenile yellowfin tuna $(21-78 \mathrm{~cm})$.
\end{abstract}

Keywords: Pelagic fish, species composition, Sendang Biru, skipjack tuna, yellowfin tuna

\section{INTRODUCTION}

As the tropical coastal zone, Indonesia has the potential of highly diverse fish communities (Longhurst and Pauly 1987; Case et al. 2007). Moreover, Indonesia is an archipelago country with a coastline of more than 81,000 $\mathrm{km}$, which provide high biodiversity of fishes that estimated to be 2.500 species of fishes (Setyaningrum 2013). Sendang Biru is the one of Indian Ocean water in East Java that rich of pelagic fish species primarily the yellowfin tuna (Thunnus albacares) and skipjack tuna (Katsuwonus pelamis) (Jaya et al. 2017; Hidayati 2018).

The fishing activities at Sendang Biru beach are the main livelihood for the people in the area. Fishing activities have a direct and indirect impact on the composition and abundance of pelagic catch fish. The direct impact of fishing activities is the reduction in fish biomass, thereby reducing one trophic level in an ecosystem, while the indirect impact is the capture of non-target species, habitat damage and changes in fish behavior. In addition, environmental changes also affect the composition and abundance of pelagic fish. Moreover, the biomass and biodiversity of marine ecosystems have now experienced a decline in their natural conditions (Stergiou et al. 2007; Crowder et al. 2008). The increasing of seawater temperature due to the climate change considerably contributes to the changes of marine species abundance and composition (Portner and Peck 2010). Understanding the structure and fish community dynamics is required for the fisheries management, such as to formulate the exploitation strategy toward the fisheries resources. (Brander 1988; Sainsbury 1982).

The composition of catch is characterized by the use of different fishing gears as well as the species target that exploited (Vazquez 2008). Information of targeted fish species and body size relating to the different fishing gear categories and methods is an important dataset for comparing the temporal and spatial selectivity between fishing gears (Stamatopoulos 2002). Troll line is the fishing gear that most used by Sendang Biru fishermen with the expected target of the tuna fish. Trolling line is the handhauled fishing gear, that consists of a line with natural or artificial baited hooks (FAO 2018). It has several advantages, including the relatively simple to operate, cheap and can use the artificial baited hooks (Ayodhya 1981).

The biological information of fish species composition that caught by the main fishing gear in Sendang Biru, namely trolling line is required to assess the fish stocks status that essential for management of sustainable fisheries. The study was focused on species, and body size composition to provides scientific information of the troll line selectivity toward the natural resources including commercial fisheries in Sendang Biru. Moreover, the study of length body size was conducted to estimate the commercial fish ages (Sparre and Venema 1998) and the development stage that essential to avoid the overfishing of immature or mature catch fishes. 


\section{MATERIALS AND METHODS}

\section{Study area}

The fish samples were collected from the vessel that used the fishing gear of troll line that landing at the Commercial Fishing Port of Sendang Biru ( $8^{\circ} 43^{\prime} 50.19$ "S, $\left.112^{\circ} 68^{\prime} 22.33^{\prime \prime} \mathrm{E}\right)$, Malang District, East Java, Indonesia in April 2018. Fish samples analysis was carried out at the Zoology and Animal Engineering Laboratory, Department of Biology, Science Faculty, Institut Teknologi Sepuluh Nopember (ITS), Surabaya, Indonesia.

\section{Procedures}

\section{Preparation}

The preliminary survey to figure out the active day and time of landing fishing vessel and the type of fishing gear at Sendang Biru Commercial Fishing Port was performed before sampling of fishes. The fishermen were interviewed to collect the information of their vessel and fishing area.

\section{Sample, data collection and analysis}

Data that are used in this study including the secondary data from the database of The Fisheries Port Information Center of Sendang Biru, and primary data of the fish samples that obtained from the fishing vessels that using the troll line and landed at Sendang Biru Commercial Fishing Port. There were nine selected vessels that could represent the different fishing area. The total amount of catch fishes and its body length from each vessel were measured on site for three days. Data of fishes body length were used to determine the developmental stages which include juvenile, pre-adult, an adult according to Froese and Pauly (2005). Several fishes from each species were brought to the laboratory for further morphometric analysis for identification purposes and photographed for documentation. Moreover, the relative abundance (RA) of species and RA of developmental stages was calculated. The RA is the percent composition of an organism of a particular kind relative to the total number of organisms in the area (Walag and Canencia 2016), with the formula below:

RA $(\%)=($ Number of individuals per species/ Total number of individuals $) * 100$

\section{RESULTS AND DISCUSSION}

\section{The composition and relative abundance of catch fish species}

This research found four species of fishes that caught by troll line of nine landing vessels in Sendang Biru East Java, i.e Katsuwonus pelamis (skipjack tuna); Thunnus albacares (yellowfin tuna); Coryphaena hippurus (common dolphinfish) and Makaira mazara (blue marlin) which identified according to the morphological and morphometric characters (Figure 2 and Table 1).

The fish catch data from nine vessels that used troll line in Sendang Biru landing port included morphometric data and total amount of catches are shown in Table 1.

Thunnus albacares (yellowfin tuna) and $K$. pelamis (skipjack tuna) are the most catch fish species from each vessel. Through interviews of fishers, those two species are the target species due to their high economic value. Table 2 showed that the relative abundance (RA) of fishing catches are dominated by Scrombidae, i.e., skipjack tuna (50.11\%) and yellowfin tuna (47.95\%). Meanwhile, the RA value of common dolphinfish and blue marlin were low, i.e., $1.88 \%$ and $0.1 \%$ respectively.

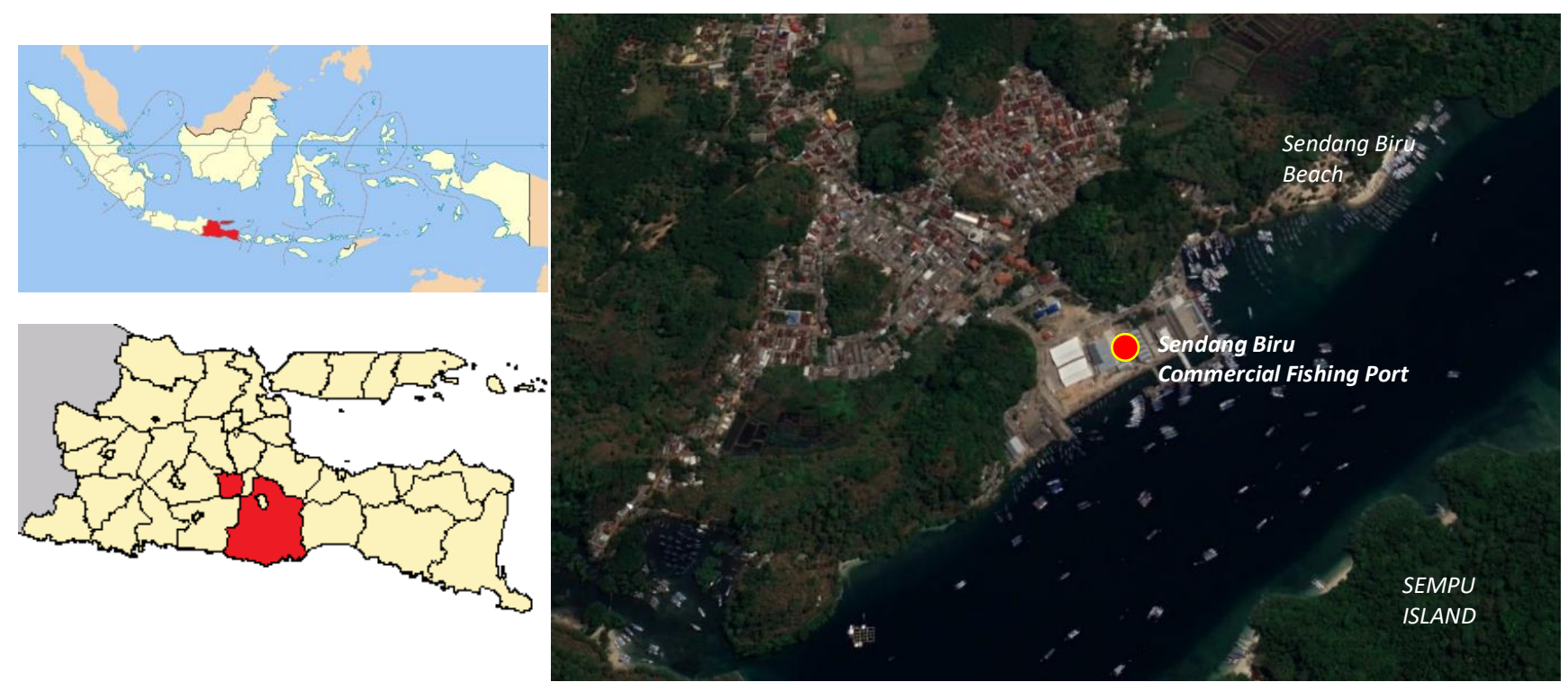

Figure 1. Location of fishes sampling in the Sendang Biru Commercial Fishing Port (O) in Malang District, East Java, Indonesia. The Sendang Biru is the coastal part of Indian Ocean water 

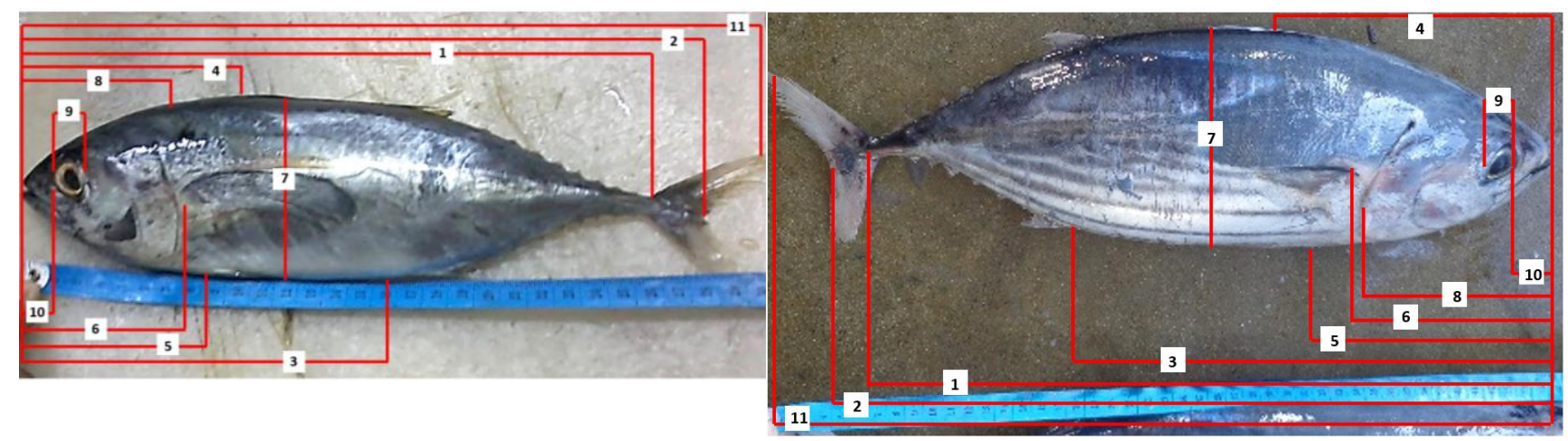

A

B

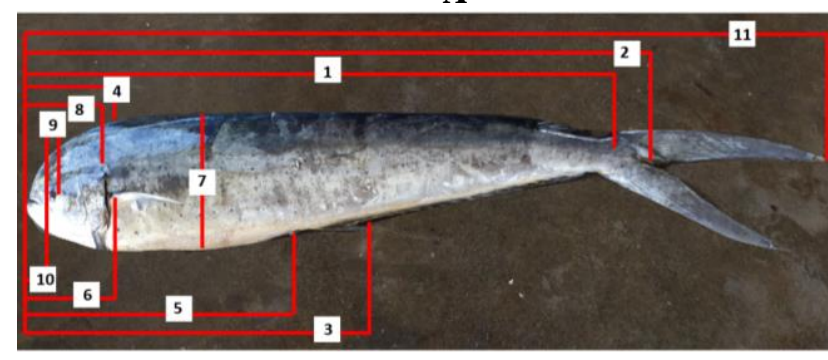

C

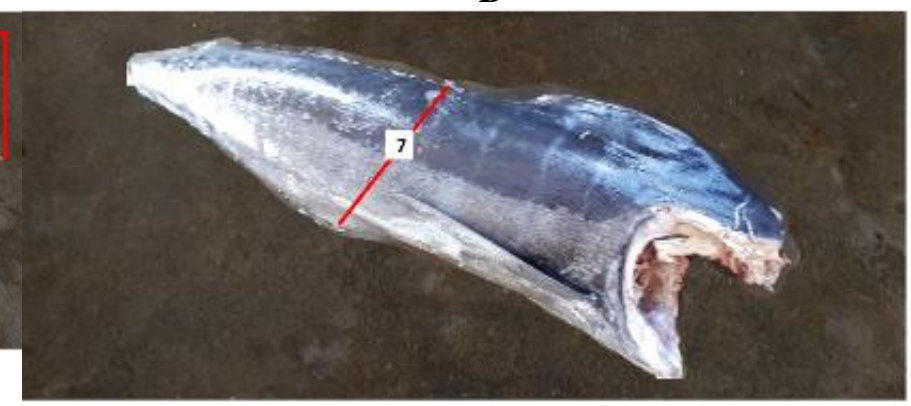

D

Figure 2. Fishes that caught by troll line from nine landing vessels in Sendang Biru Fishes, Malang, Indonesia. A. Thunnus albacares (yellowfin tuna); B. Katsuwonus pelamis (skipjack tuna); C. Coryphaena hippurus (common dolphinfish); D. The body part of Makaira mazara (blue marlin). Note: Fishes were identified according to the morphological and morphometric characters including: Standard length (1); Fork length (2); Pre-anal length (3); Pre-dorsal length (4); Pre-pelvic length (5); Pre-pectoral length (6); Body depth (7); Head length (8); Eye diameter (9); Pre-orbital length (10); Total Length (11). Exception: M. Mazara was identified only based on morphological characters.

Table 1. Fish catch data: morphometric data and sampling size (n)

\begin{tabular}{llccc}
\hline Fish catch data & & $\begin{array}{c}\text { T. albacares } \\
\text { (yellowfin tuna) }\end{array}$ & $\begin{array}{c}\text { K. pelamis } \\
\text { (skipjack tuna) }\end{array}$ & $\begin{array}{c}\text { C. hippurus } \\
\text { (common dolphinfish) }\end{array}$ \\
\hline Morphometric characters and percentage & Standard length & $87.4 \% \mathrm{TL}$ & $90.4 \% \mathrm{TL}$ & $83.9 \% \mathrm{TL}$ \\
of body size for identification purpose & Fork length & $91.0 \% \mathrm{TL}$ & $94.6 \% \mathrm{TL}$ & $86.0 \% \mathrm{TL}$ \\
& Pre-anal length & $55.3 \% \mathrm{TL}$ & $63.4 \% \mathrm{TL}$ & $45.0 \% \mathrm{TL}$ \\
& Pre-dorsal length & $43.2 \% \mathrm{TL}$ & $30.2 \% \mathrm{TL}$ & $10.3 \% \mathrm{TL}$ \\
& Pre-pelvic length & $26.4 \% \mathrm{TL}$ & $28.5 \% \mathrm{TL}$ & $18.2 \% \mathrm{TL}$ \\
& Pre-pectoral length & $26.1 \% \mathrm{TL}$ & $26.1 \% \mathrm{TL}$ & $16.8 \% \mathrm{TL}$ \\
& Body depth & $26.1 \% \mathrm{TL}$ & $24.0 \% \mathrm{TL}$ & $18.9 \% \mathrm{TL}$ \\
& Head length (HL) & $21.2 \% \mathrm{TL}$ & $25.5 \% \mathrm{TL}$ & $18.2 \% \mathrm{TL}$ \\
& Eye diameter & $14.6 \% \mathrm{HL}$ & $16.5 \% \mathrm{HL}$ & $20.4 \% \mathrm{HL}$ \\
Total Length (TL) in cm & Pre-orbital length & $25.2 \% \mathrm{HL}$ & $25 \% \mathrm{HL}$ & $23.8 \% \mathrm{HL}$ \\
Sample size (n) & & $43.62 \pm 6.28$ & $43.50 \pm 7.54$ & $100.21 \pm 14.08$ \\
\hline
\end{tabular}

Table 2. The relative abundance (RA) of fishing catches

\begin{tabular}{llc}
\hline Family & Species & $\begin{array}{c}\text { Relative } \\
\text { abundance } \\
(\mathbf{\%})\end{array}$ \\
\hline Scombridae & T. albacares (Yellowfin tuna) & 47.95 \\
& K. pelamis (Skipjack tuna) & 50.05 \\
Coryphaenidae & C. hippurus (Common dolphinfish) & 1.88 \\
Istiophoridae & M. mazara (Blue marlin) & 0.11 \\
& & \\
\hline
\end{tabular}

\section{The body size composition of catch fishes}

The adult size of yellowfin is in the range of fork length $78-158 \mathrm{~cm}$; skipjack fish with a range of fork lengths of 40$45 \mathrm{~cm}$; common dolphinfish fish with a range of fork length sizes $35-93.1 \mathrm{~cm}$; while blue marlin fish with a range of fork length sizes of more than $50 \mathrm{~cm}$ (Froese and Pauly 2005). In the current study, the fork length of the catch fishes, then compared to the reference of fish body size according to Froese and Pauly (2005), indicated that the catch fishes were found in both stages of juvenile and adult. The relative abundance of juvenile and adult fishes based on body length is presented in Table 3 . 
Table 3. The relative abundance (RA) of juvenile and adult fishes based on body length

\begin{tabular}{|c|c|c|c|c|c|c|c|c|c|c|c|c|}
\hline \multirow{3}{*}{$\begin{array}{c}\text { Fish } \\
\text { size range }(\mathrm{cm})\end{array}$} & \multicolumn{3}{|c|}{$\begin{array}{c}\text { T. albacares } \\
\text { (Yellowfin tuna) }\end{array}$} & \multicolumn{3}{|c|}{$\begin{array}{c}\text { K. pelamis } \\
\text { (Skipjack tuna) }\end{array}$} & \multicolumn{3}{|c|}{$\begin{array}{c}\text { C. hippurus } \\
\text { (Common dolphinfish) }\end{array}$} & \multicolumn{3}{|c|}{$\begin{array}{c}\text { M. mazara } \\
\text { (Blue marlin) }\end{array}$} \\
\hline & \multirow{2}{*}{$\begin{array}{l}\text { Sample } \\
\text { size (n) }\end{array}$} & \multicolumn{2}{|c|}{ RA (\%) } & \multirow{2}{*}{$\begin{array}{l}\text { Sample } \\
\text { size (n) }\end{array}$} & \multicolumn{2}{|c|}{$\mathbf{R A}(\%)$} & \multirow{2}{*}{$\begin{array}{l}\text { Sample } \\
\text { size (n) }\end{array}$} & \multicolumn{2}{|c|}{ RA (\%) } & \multirow{2}{*}{$\begin{array}{l}\text { Sample } \\
\text { size (n) }\end{array}$} & \multicolumn{2}{|c|}{ RA (\%) } \\
\hline & & $\mathbf{J}$ & A & & $\mathbf{J}$ & A & & $\mathbf{J}$ & A & & $\mathbf{J}$ & A \\
\hline $21-30$ & 9 & 2,07 & - & 17 & 3.76 & & - & - & & - & - & \\
\hline $31-40$ & 272 & 62.81 & - & 154 & 34.07 & & - & - & & - & - & \\
\hline $41-50$ & 140 & 32.33 & - & 260 & - & 57.52 & - & - & & - & - & \\
\hline $51-60$ & 2 & 0.46 & - & 21 & - & 4.65 & 1 & - & 5.88 & - & - & \\
\hline $61-70$ & 8 & 1.84 & - & - & - & & - & - & - & - & - & \\
\hline $71-80$ & 1 & 0.23 & - & - & - & & 3 & - & 17.65 & - & - & \\
\hline $81-90$ & 0 & - & - & - & - & - & 8 & - & 47.06 & - & - & - \\
\hline $91-100$ & 1 & - & 0.23 & - & - & - & 4 & - & 23.53 & - & - & - \\
\hline $101-110$ & 0 & - & - & - & - & - & - & - & - & - & - & - \\
\hline $111-120$ & 0 & - & - & - & - & - & 1 & - & 5.88 & 1 & - & 100 \\
\hline Total & 433 & 99.76 & 0.23 & 452 & 37.7 & 62.3 & 17 & - & 100 & 1 & - & 100 \\
\hline
\end{tabular}

Note: $\mathrm{RA}=$ Relative abundance; $\mathrm{J}=$ Juvenile; $\mathrm{A}=$ Adult

The yellowfin tuna was dominated by the fork length between $21-78 \mathrm{~cm}$, which categorized as the stage of juvenile $(99.76 \%)$, primarily at fork length of $31-40 \mathrm{~cm}$. Contrary, the skipjack tuna was dominated by adult size $(62,3 \%)$, which ranges from $41-50 \mathrm{~cm}$. Meanwhile, the rest of catch fishes, i.e. dolphin fish and blue marlin, $100 \%$ were caught in the adult size.

\section{Discussion}

The composition and relative abundance of catch fish species

Target species dominated the composition and relative abundance of catch species, i.e. yellowfin tuna and skipjack tuna suggesting that the fishing area in Sendang Biru provide the expected and beneficially catches. This current study is consistent with the previous research that reported the yellowfin tuna as the main catch fish in Sendang Biru (Hidayati 2018).

The high relative abundance (RA) of catching yellowfin tuna $(47.95 \%)$ and skipjack tuna $(50.05 \%)$ possibly occurred since the troll line is operated together with the application of the Fish Aggregating Devices (FADs) as a supporting tool for fishing activity. Fromentin and Fonteneau (2001) revealed that skipjack tuna and yellowfin tuna are the dominance catch fish in FADs at RA value of $63 \%$ and $25 \%$ respectively.

However, the yield of catch fishes at Sendang Biru during this study (April 2018), was relatively small compared to the other months. Faizah et al. (2011) reported that the number of catches of yellowfin in April was very small compared to October. This condition may be influenced by the seasonal factors on tuna fishing. During April, the west monsoon was blowing in the waters of the Indian Ocean caused downwelling. According to Yoga et al. (2014) in December-March, the northwest monsoon blows while during the months of June-October the southeast monsoon blows. During the northwest monsoon, southern waters of Java experience downwelling, whereas during southeast monsoon they experience upwelling (Yoga et al. 2014). Nontji (1987) states that upwelling in Indonesian waters is seasonal, especially in the waters of
South Java occurring in May-September. In April, the phenomenon of decreasing downwelling in the southern waters of Java was thought to have caused phytoplankton to be carried into deeper water columns. In other words, the waters of south Java do not become productive, so the number of catches is low (Yoga et al. 2014). This is confirmed by the study of Nurani et al. (2012) regarding the Catching Season Index (IMP), known that the season Tuna fishing in the waters of the South Indian Ocean in East Java occurs in May-September, with peaks occurring in June.

Sustainable fish management in Sendang Biru is crucial, since this region well known as the area with the high catch of tuna (Zarochman 2010; Jaya et al. 2017). The fish stock abundance including the spatial and seasonal aspects are of significant importance for management decisions (Mulazzani et al. 2014). Furthermore, this current study provides important data of fish stock mainly in low catch season at Sendang Biru that are needed for fisheries management in Indonesia.

\section{The body size composition of catch fishes}

The measurement of fish body length is crucial for fish stock assessment since the length body size is used for estimates the fish age and its stage development (Hannah et al. 2009). The occurrence of adult skipjack tuna together with the juvenile Yellowfin tuna in the same catch has correlated with the swimming layer (depth of fish swimming). The small yellowfin tuna will be schooled with skipjack tuna because it has a similar size (Wahju et al. 2013). Fish gathered around, are influenced by behavior and size of fish where fish are small size near the surface. According to Barata et al., (2011) research shows that yellowfin species are caught in the Indian Ocean in the depth range of $86-168 \mathrm{~m}$

Table 3 showed that adult skipjack and juvenile of yellowfin tuna are the most caught species. This is because yellowfin tuna and skipjack tuna have the same life habits, forming schools around FADs. Skipjack tuna is often found to be clustered with juvenile yellowfin tuna and bigeye 
tuna (Kurniawan 2015). The 62.3\% skipjack was caught in adult fork length size $(>40 \mathrm{~cm})$ which size was fit with the allowed length for a caught fish. While the most catch yellowfin tuna $(99.78 \%)$ were found at fork length $<78 \mathrm{~cm}$, which was categorized as a juvenile and not suitable for catching.

The high number catch of yellowfin tuna at juvenile stage allegedly due to the use of the fishing rod in the troll line that can be adjusted depending on the water condition. According to the interview with the fishers revealed that during April, the waves in the Sendang Biru waters were high so that fishers catching fish in more shallow waters that in consequence, causing the catch fishes to be smaller. Another reason for a large number of juvenile tuna caught is the effectiveness of fishing operations using the FADs. FADs is equipped with attractors which function to attract fish to gather around FADs, which followed by the formation of a food network, causing the fishing operations to be easier (Sondita, 2011). Juvenile tuna is often found around FADs (Harley et al. 2010). Another result of this study showed that the troll line has catches fishes with a size that is not fit to be caught, such as tuna babies. (Nurani et al. 2012). Moreover, some researchers prove that tuna catches with FADs have a small size.

It can be concluded that pelagic fishes that caught by troll line at the vessel that landed in Sendang Biru port consist of four pelagic fishes species which dominated by $K$. pelamis or skipjack tuna $(50.05 \%)$ and $T$. albacares or yellowfin tuna (47.95\%) and a small amount of Coryphaena hippurus and Makaira mazara. According to the body size, the fish caught by troll line in Sendang Biru is dominated by adult skipjack tuna $(99.76 \%)$, with the size between 41-60 cm, and juvenile yellowfin tuna that have a size between $21-78 \mathrm{~cm}$, primarily at fork length of $31-40$ $\mathrm{cm}$.

\section{ACKNOWLEDGEMENTS}

This study was supported by a research grant from Institut Teknologi Sepuluh Nopember Surabaya (ITS) Indonesia. The chemical and biological analyses were conducted at the Laboratory of Zoology and Animal Engineering, Biology Department, ITS, Surabaya, Indonesia.

\section{REFERENCES}

Allen G. 1999. Marine Fishes of South-East Asia. Periplus Editions (HK) Ltd, Singapore.

Ayodhya AU. 1981 Fishing Technique.. Published by Yayasan Dewi Sri, Bogor. [Indonesiann].

Barata AD, Novianto A, Bahtiar. 2011. Distribution of tuna based on temperature and depth in the Indian Ocean. Ilmu Kelautan 16 (3): 165-170. [Indonesian].

Brander K. 1988. Multispecies Fisheries of the Irish Sea. In: J. Gulland (Ed). Fish Populations Dynamics (2nd Ed). Wiley, New York.

Case M, Ardiansyah F, Spector E. 2007. Climate change in Indonesia implications for humans and nature. WWF. http://awsassets.panda.org

Crowder LB, Hazen, Elliott L, Naomi ARB, Catherine L, Matthew B, Ogburn. 2008. The Impacts of fisheries on marine ecosystems and the transition to ecosystem-based management Annu. Rev. Ecol Evol Syst 39: 259-278.

Faizah, Ria, Aisyah. 2011. The type composition and size distribution of large pelagic fish from fishing catch at Sendang Biru, East Java. BAWAL 3 (6): 377-385.

FAO. 2018. The State of World Fisheries and Aquaculture 2018 - Meeting the sustainable development goals. Rome. License: CC BY-NC-SA 3.0 IGO. http://www.fao.org/3/i9540en/i9540en.pdf

Fromentin, Fonteneau. 2001. Fishing effects and life history traits: a case study comparing tropical versus temperate tunas. Fisheries Research Journal 53 (2): 133-150

Froese R, Pauly D. 2005. Fish Base. World Wide Web electronic publication.www.fishbase.org

Hannah RW, Blume MT, Thompson JE. 2009. Length and age at maturity of female yelloweye rockfish (Sebastes ruberrimus) and cabezon (Scorpaenichthys marmoratus) from Oregon waters based on histological evaluation of maturity. Information reports number 200904. Oregon Department of Fish and Wildlife Marine Resources Program2040 Southeast Marine Science Drive, Newport, Oregon, USA.

Harley SJ, Williams P, Hampton J. 2010. Characterization of ‘purse seine fishing activities during the 2009 FAD closures. Indonesia Sixth regular session of the WCPFC Scientific Committee, Aug. 10-19, 2010, Nuku'alofa, Tonga. WCPFC-SC6-2010/FT-WP-03.

Hidayati D, Herlambang R, Jadid N, Saadah NN. 2018. Potential of yellowfin tuna caught in East Java-Indian Ocean based on length frequency and age distribution. Journal of Physics Conference Series 1040 (1): 012-007.

Kurniawan W. 2015. Season of skipjack tuna catching in West Java Waters and its relation to oceanographic parameters. Oseana 40 (4) : 53 - 60 [Indonesian]

Jaya MM, Wiryawan B, Simbolon D. 2017. Sustainability of Tuna Fisheries in Sendangbiru Malang District (Keberlanjutan Perikanan Tuna di Perairan Sendangbiru Kabupaten Malang). ALBACORE I (1): 111-125

Longhurst AR, Pauly D. 1987. The Ecology of Tropical Oceans. Academic Press, Inc. San Diego, USA.

Mulazzani L, Manrique R, Trevisan G, Piccinetti C, Malorgioa G. 2014. The relationship among catch, fishing effort, and measures of fish stock abundance: implications in the Adriatic Sea. Canadian J Fisher Aquat Sci 72 (3): 410-421.

Nurani TW, Wahyuningrum PI, Mustaruddin, Maarif R, Wiratama B. 2012. Performance catch of tuna from troll line in rumpon. Mar Fisher 3 (1): 1-6.

Nontji A. 1987. Nusantara Sea. Publish by Djambatan, Jakarta.[Indonesian]

Portner HO, Peck MA. 2010. Climate change effects on fishes and fisheries: towards a cause-and-effect understanding. J Fish Biol 77 (8): 1745-1779

Sainsbury K. 1982. The ecological basis of tropical fisheries management. p. 167-188. In Pauly D, Murphy G (eds.). Theory and Management of Tropical Fisheries. ICLARM Conference Proceedings, 9, Manila, Philippines.

Setyaningrum EW. 2013. Determination of the right and sustainable types of pelagic fishing equipment in supporting increased capture fisheries in Muncar, Banyuwangi Regency, Indonesia. J-PAL 4 (2): 45-50. [Indonesian]

Sondita MFA. 2011. A Perspective: FADs as a Fish Resource Management tool. Book II New Paradigm in Marine Fisheries. Institut Pertanian Bogor, Bogor. [Indonesian]

Sparre P., Venema S. C. 1998. Introduction to tropical fish stock assessment, Part I: Manual. FAO Fisheries Technical Paper 306: 1. FAO, Rome.

Stamatopoulos C. 2002. Sample-based fishery surveys: A technical handbook. FAO Fisheries Technical Paper. No. 425. FAO, Rome.

Stergiou KI, Moutopoulos DK, Hernando JAC, Hernando JA, Erzini K. 2007. Trophic signatures of small scale fishing gears: implications for conservation and management. Mar Ecol Prog Ser 333:117-128

Vazquez M. 2008. Invasive Swimming Crabs: Development of Eradicating Trapping Gear and Methods. In: Wilcox CP, Turpin RB. (eds.). Invasive Species: Detection, Impact and Control. Nova Science Publishers, New York.

Wahju RI, Zulbainarni N, Soeboer DA. 2013. Troll line fishing results based on seasonal capture and areas of tuna capture using Fish Aggregating Device (FAD) in the south Pelabuhan Ratu waters. Buletin PSP. 21 (1): 97-105. [Indonesian] 
Walag AMP, Canencia MOP. 2016. Physico-chemical parameters and macrobenthic invertebrates of the intertidal zone of Gusa, Cagayan de Oro City, Philippines. AES Bioflux 8: 71-82.

Yoga B, Bima R, Soetyono H, Harsono G. 2014. The dynamics of upwelling and downwelling based on the variability of sea surface temperature and chlorophyll-a in the Southern Waters of Java. Jurnal Oseanografi 3 (1): 57-66.. [Indonesian]

Zarochman. 2010. Fishing and catch performance of the tropical tuna fisheries in The Indian Ocean. IOTC-2010-WPTT-38. IOTC-WPTT Meeting, Seychelles, October 2010. 